\title{
Regulation of the switch from early to late bacteriophage $\lambda$ DNA replication
}

\author{
Sylwia Barańska, ${ }^{1}$ Magdalena Gabig, ${ }^{2}$ Alicja Węgrzyn, ${ }^{2}$ \\ Grażyna Konopa, ${ }^{1}$ Anna Herman-Antosiewicz, ${ }^{1}$ Pablo Hernandez, ${ }^{3}$ \\ Jorge B. Schvartzman, ${ }^{3}$ Donald R. Helinski ${ }^{4}$ and Grzegorz Weggrzyn ${ }^{1,5}$
}

\footnotetext{
1,2 Department of Molecular Biology, University of Gdańsk ${ }^{1}$ and Laboratory of Molecular Biology (affiliated with the University of Gdańsk), Institute of Biochemistry and Biophysics, Polish Academy of Sciences², Kładki 24, 80-822 Gdańsk, Poland

3 Departamento de Biología Celular y del Desarrollo, Centro de Investigaciones Biológicas (CSIC), Velázquez 144, 28006 Madrid, Spain

${ }^{4}$ Center for Molecular Genetics and Department of Biology, University of California at San Diego, 9500 Gilman Drive, La Jolla, CA 92093, USA

${ }^{5}$ Marine Biology Center, Polish Academy of Sciences, Św. Wojciecha 5, 81-347 Gdynia, Poland
}

Author for correspondence: Grzegorz Węgrzyn. Tel: +48 58346 3014. Fax: +48 583010072. e-mail:wegrzyn@biotech.univ.gda.pl

\begin{abstract}
There are two modes of bacteriophage $\lambda$ DNA replication following infection of its host, Escherichia coli. Early after infection, replication occurs according to the theta ( $\theta$ or circle-to-circle) mode, and is later switched to the sigma ( $\sigma$ or rolling-circle) mode. It is not known how this switch, occurring at a specific time in the infection cycle, is regulated. Here it is demonstrated that in wildtype cells the replication starting from ori $\lambda$ proceeds both bidirectionally and unidirectionally, whereas in bacteria devoid of a functional DnaA protein, replication from ori $\lambda$ is predominantly unidirectional. The regulation of directionality of replication from ori $\lambda$ is mediated by positive control of $\lambda p_{R}$ promoter activity by DnaA, since the mode of replication of an artificial $\lambda$ replicon bearing the $p_{\text {tet }}$ promoter instead of $p_{R}$ was found to be independent of DnaA function. These findings and results of density-shift experiments suggest that in dnaA mutants infected with $\lambda$, phage DNA replication proceeds predominantly according to the unidirectional $\theta$ mechanism and is switched early after infection to the $\sigma$ mode. It is proposed that in wild-type $E$. coli cells infected with $\lambda$, phage DNA replication proceeds according to a bidirectional $\theta$ mechanism early after infection due to efficient transcriptional activation of ori $\lambda$, stimulated by the host DnaA protein. After a few rounds of this type of replication, the resulting increased copy number of $\lambda$ genomic DNA may cause a depletion of free DnaA protein because of its interaction with the multiple DnaA-binding sites in $\lambda$ DNA. It is proposed that this may lead to inefficient transcriptional activation of ori $\lambda$ resulting in unidirectional $\theta$ replication followed by $\sigma$ type replication.
\end{abstract}

Keywords: bacteriophage $\lambda$ development, Escherichia coli DnaA protein, rolling-circle DNA replication, theta DNA replication, transcriptional activation of origin

\section{INTRODUCTION}

Bacteriophage $\lambda$ has played a crucial role in the development of molecular biology (Thomas, 1993; Gottesman, 1999). It is a paradigm of molecular mechanisms of many general biological processes including DNA replication and it still serves as an important model system for molecular biology research. For example, the results obtained with $\lambda$ replicons were successfully employed in studies on eukaryotic DNA replication (Stillman, 1994), and mechanisms of replication of some animal viruses (e.g. herpes simplex virus) resemble those found in $\lambda$ (Kornberg \& Baker, 1992; Subak-Sharpe \& Dargan, 1998).
The genome of bacteriophage $\lambda$ consists of $48502 \mathrm{bp}$ of double-stranded DNA (see Fig. 1). In the $\lambda$ virion, this genetic material is packaged in a linear form in the head of the phage capsid. After adsorption to the surface of its host, Escherichia coli, and penetration of the phage genome into the bacterial cell, the linear DNA is immediately converted into the circular form due to single-stranded $5^{\prime}$ extensions of 12 bases at both ends, which are complementary to each other. The ends are ligated by the host DNA ligase and, following the action of $E$. coli DNA gyrase, the phage genome becomes a negatively supercoiled structure (for recent reviews on $\lambda$ DNA replication and phage development see Taylor \& Węgrzyn, 1995, 1998). 
(a)

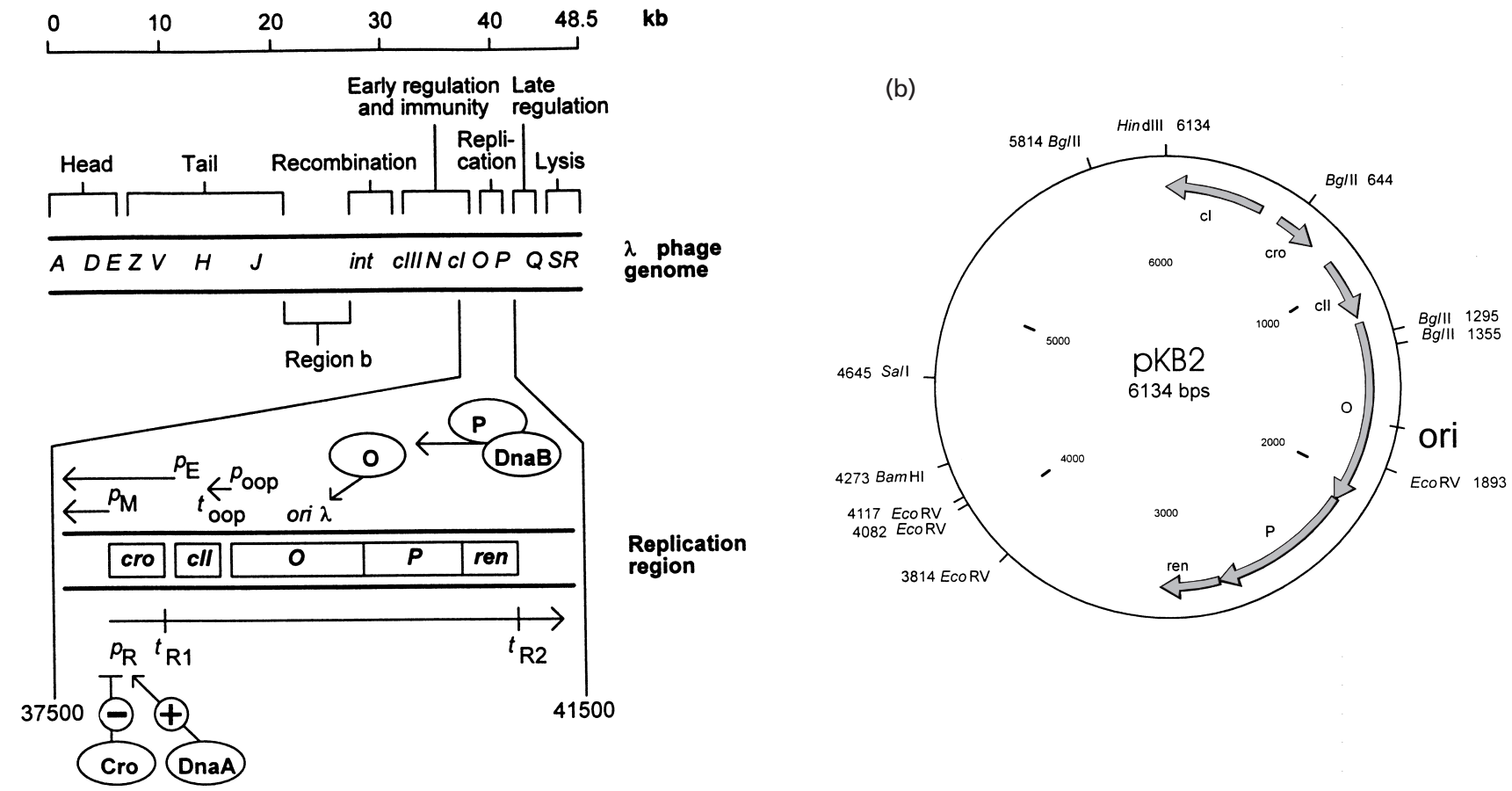

Fig. 1. (a) A genetic map of bacteriophage $\lambda$ with the replication region enlarged. Positions of certain important genes are marked. The replication region of the $\lambda$ genome (present also in a typical $\lambda$ plasmid) is presented in the lower part of the figure. All promoters and terminators present in the replication region are indicated. Actions of proteins forming the preprimosomal complex at ori $\lambda$, and repression and stimulation of the $p_{R}$ promoter by Cro and DnaA, respectively, are indicated. (b) A map of $\lambda$ plasmid pKB2 with marked $\lambda$ genes and restriction sites used in this work during analysis of the directionality of replication by two-dimensional agarose gel electrophoresis and electron microscopy. pKB2 $\pi$ is a pKB2 derivative bearing a single nucleotide substitution, C to A at nucleotide 422 of the $P$ gene (Wegrzyn et al., 1996).

The $\lambda$-encoded replication proteins $\mathrm{O}$ and $\mathrm{P}$ are synthesized early after phage infection, since the $\mathrm{O}-\mathrm{P}$ region is situated downstream of the $p_{\mathrm{R}}$ promoter and the weak $t_{\mathrm{R} 1}$ terminator (Fig. 1). The $\mathrm{O}$ protein is a prototype initiator protein, which binds to the origin of replication, ori $\lambda$, and directs other viral and host replication proteins (including DnaB helicase) to this site in the process of replication complex assembly. Loading of DnaB helicase (liberated from P-mediated inhibition by DnaK, DnaJ and GrpE proteins) seems to be connected with the $p_{\mathrm{R}^{-}}$ initiated transcriptional activation of ori $\lambda$, which is stimulated by the host DnaA function (A. Wegrzyn et al., 1995a; G. Węgrzyn et al., 1995a; Węgrzyn et al., 1996; Szalewska-Pałasz et al., 1998a). This allows for the establishment of bidirectional $\theta$ replication of the $\lambda$ genome, which is observed at the early stages of infection (Schnos \& Inman, 1970). In an in vitro system reconstituted from purified proteins (and lacking HU protein), $\lambda$ DNA replication was shown to be independent of transcription (Alfano \& McMacken, 1989a, b; Żylicz et al., 1989) while proceeding unidirectionally (Mensa-Wilmot et al., 1989). However, addition of RNA polymerase resulted in the appearance of a significant fraction of $\lambda$ DNA molecules replicating bidirectionally (Learn et al., 1993).

After five to six rounds of bidirectional $\theta$ replication, about 50 copies of the circular $\lambda$ genome appear in the infected host cell. Then, at about $15 \mathrm{~min}$ post-infection, a few of these molecules start to replicate according to the $\sigma$ mode (Taylor \& Wegrzyn, 1995, 1998). This leads to the production of long concatemers of $\lambda$ DNA, up to about ten genome equivalents in length, which are cut at specific sites (called cos sites) and serve as the substrates for the phage packaging system. The mechanism of the switch from $\theta$ to $\sigma$ replication has not been completely elucidated, but according to the predominant hypothesis, originally proposed by Dodson et al. (1986), $\sigma$ may be preceded by one round of unidirectional $\theta$ replication initiated at ori $\lambda$, followed by displacement of the $5^{\prime}$ end of the newly synthesized leading strand by its growing $3^{\prime}$ end.

Although the mechanism of the switch from $\theta$ to $\sigma$ replication has been proposed (see above), it remains unknown how this process is regulated and what triggers the change in the replication mode of $\lambda$ DNA. We have found previously that the host $d$ naA gene function has a role in phage $\lambda$ replication (G. Wegrzyn et al., 1995b). The findings that (i) DnaA stimulates transcriptional activation of orid (G. Węgrzyn et al., 1995a; SzalewskaPałasz et al., 1998a); (ii) transcription is necessary for bidirectional $\theta$ replication of $\lambda$ DNA in vitro (Learn et al., 1993); (iii) unidirectional $\theta$ replication is considered as a prerequisite for $\sigma$ replication (Dodson $e t$ al., 1986); and (iv) $\sigma$ replication intermediates of the phage bearing 
mutations in the $P$ gene appear early after infection of the dnaA host (G. Weegrzyn et al., 1995b; Konopa et al., 2000), suggested that DnaA may be a crucial factor in triggering the switch from $\theta$ to $\sigma$ replication of phage $\lambda$ DNA in infected E. coli cells. Therefore, the aim of this work was to investigate the mechanism of regulation of this switch in wild-type $\lambda$ phage and the role of the DnaA protein in this process.

\section{METHODS}

Bacterial strains, phages and plasmids. Escherichia coli wildtype strain MG1655 (Jensen, 1993) and its dnaA46(ts) tnaA::Tn10 derivative (strain BM746), constructed by P1 transduction from strain BM215 (A. Wegrzyn et al., 1995b), were used. An isogenic pair of $d_{n a A^{+}}$and $d n a A:: \mathrm{cm}$ (dnaA null) strains were also employed: this pair consists of the dnaA::cm strain TC3478 [dnaA::cm araD139 $\Delta$ (ara-leu) $\Delta$ lacX74 galK galU hsdR rnh-373 rpsL thi], which was described by Ingmer $\&$ Atlung (1992), and its $d n a A^{+} z i d-$ 3162:: Tn10kan derivative (BM3477), which was constructed by P1 transduction from strain CAG18558, described by Singer et al. (1989). Phages $\lambda c I b 2$ and $\lambda$ red3cl857S7 (G. Węgrzyn et al., 1995b) were used. $\lambda$ plasmids pKB2 and pKB2 $\pi$ have already been described by Kur et al. (1987). Plasmid pTC $\lambda 1$, an artificial $\lambda$ plasmid bearing the $p_{\text {tet }}$ promoter instead of $p_{\mathrm{R}}$, was constructed by Herman-Antosiewicz et al. (1998a)

One-step growth experiments. Lytic development of bacteriophage $\lambda$ was investigated by one-step growth experiments as described previously (G. Węgrzyn et al., 1995b). Briefly, bacteria growing exponentially in $\mathrm{LB}$ medium at $30^{\circ} \mathrm{C}$ were infected by phage $\lambda c I b 2$ in the presence of $3 \mathrm{mM} \mathrm{NaN}_{3}$ (to prevent unsynchronized phage development) at the indicated m.o.i., and adsorption was carried out for $10 \mathrm{~min}$ at $43^{\circ} \mathrm{C}$. Following centrifugation, the bacterial pellet was resuspended in the same medium (with $\mathrm{NaN}_{3}$ ) containing anti- $\lambda$ serum and incubated for $5 \mathrm{~min}$ at $43{ }^{\circ} \mathrm{C}$ to neutralize unadsorbed phages. The suspension was then diluted 1000 -fold with prewarmed (to $43{ }^{\circ} \mathrm{C}$ ) medium (devoid of $\mathrm{NaN}_{3}$ ) and aerated in a waterbath shaker. The number of 'infective centres' was estimated by plating samples taken during the first $10 \mathrm{~min}$ after dilution (time $0-10 \mathrm{~min}$ ). In fact, the estimated number of 'infective centres' is the sum of the number of infected bacteria and the number of free, unadsorbed phages. However, as most of the unadsorbed phage particles were neutralized by anti- $\lambda$ serum, the second value was ignored during the calculation of the burst size. The number of intracellular progeny phage was estimated by plating chloroform-treated samples of the infected culture withdrawn at different times, using strain MG1655 as a host. The burst size was calculated as the ratio of the number of progeny phages to the number of infective centres.

Density-shift experiments. These were performed according to G. Wegrzyn et al. (1995b). Briefly, in the first type of experiment, bacteria were grown in a 'light' minimal medium (Wegrzyn, G. et al., 1995b) overnight at $30^{\circ} \mathrm{C}$, and after dilution $(1: 50, \mathrm{v} / \mathrm{v})$ with fresh medium the growth was continued to an $\mathrm{OD}_{500}$ of $0 \cdot 2$. The bacteria were pelleted, washed with TM buffer $(10 \mathrm{mM}$ Tris/ $\mathrm{HCl}, \mathrm{pH} 7 \cdot 2,10 \mathrm{mM}$ $\mathrm{MgSO}_{4}$ ) and suspended in $0 \cdot 1$ vol. of this buffer. After $60 \mathrm{~min}$ incubation at $43^{\circ} \mathrm{C},\left[{ }^{3} \mathrm{H}\right]$ thymidine-labelled phage $\left(8.3 \times 10^{-5}\right.$ c.p.m. p.f.u. ${ }^{-1}$ ) was added to a m.o.i. of 10 and incubation was continued for $15 \mathrm{~min}$. The suspension was sedimented, resuspended in the original volume of prewarmed $\left(43^{\circ} \mathrm{C}\right.$ ) 'heavy' minimal medium (containing ${ }^{15} \mathrm{NH}_{4} \mathrm{Cl}$ and

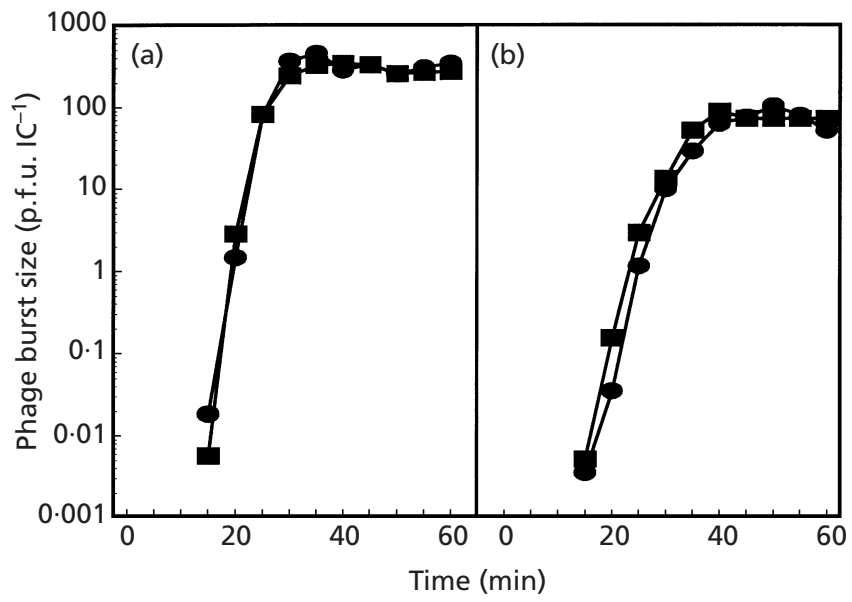

Fig. 2. Phage $\lambda \mathrm{clb} 2$ development in $E$. coli $d n a A^{+}$ (MG1655; squares) and dnaA46(ts) (BM746; circles) (a), and $E$. coli $\mathrm{dnaA}^{+}$(TC3478, squares) and $d n a A:: \mathrm{cm}$ (BM3477, circles) (b) hosts at $43^{\circ} \mathrm{C}$. Phage burst size [p.f.u. per infective centre (p.f.u. $\left.\mathrm{IC}^{-1}\right)$ ] is presented.

$\left[{ }^{13} \mathrm{C}\right]$ glucose instead of $\mathrm{NH}_{4} \mathrm{Cl}$ and glucose, respectively), and further incubation was performed at $43^{\circ} \mathrm{C}$. Samples of the infected culture were withdrawn at the indicated times, and total DNA was isolated and ultracentrifuged in a CsCl density gradient as described previously (G. Wegrzyn et al., 1995b). Fractions were collected from the bottom of the tube and the radioactivity of each fraction was measured in a scintillation counter. In the second type of experiment, the procedure was the same as described above but bacteria growing in the 'light' medium were infected with unlabelled phage (m.o.i. of 10) and further incubation was continued in the 'heavy' medium containing $0 \cdot 1 \mathrm{mCi}\left[{ }^{3} \mathrm{H}\right]$ thymidine $\mathrm{ml}^{-1}$.

Measurement of total DNA synthesis. Synthesis of DNA in cells was investigated by measurement of incorporation of $\left[{ }^{3} \mathrm{H}\right]$ thymidine into trichloroacetic acid (TCA)-precipitable material according to the method described by Wegrzyn et al. (1991). Briefly, the bacterial cultures were labelled with $0 \cdot 1 \mathrm{mCi}\left[{ }^{3} \mathrm{H}\right]$ thymidine $\mathrm{ml}^{-1}$. Samples were withdrawn at the indicated times and transferred onto paper filters. The filters were placed immediately in $10 \%$ ice-cold TCA for $5 \mathrm{~min}$, and transferred to $5 \%$ TCA for $5 \mathrm{~min}$. The samples were then washed twice with $96 \%$ ethanol and dried at room temperature. The radioactivity of the samples was measured in a scintillation counter.

Two-dimensional agarose gel electrophoresis. Analysis of replication intermediates by two-dimensional agarose gel electrophoresis was performed according to Viguera et al. (1996), with modifications described by Śrutkowska et al. (1999).

Electron microscopy. Isolation of plasmid DNA was performed according to Viguera et al. (1996) and electron microscopy analysis of replicating plasmid DNA molecules was performed as described by Burkardt \& Lurz (1984) and Śrutkowska et al. (1998).

\section{RESULTS}

\section{Phage $\lambda$ development in $E$. coli $d n a A^{+}$and $d n a A$ hosts}

Our previous studies on the role of the $d n a A$ gene in bacteriophage $\lambda$ development were performed with $E$. 
(a)
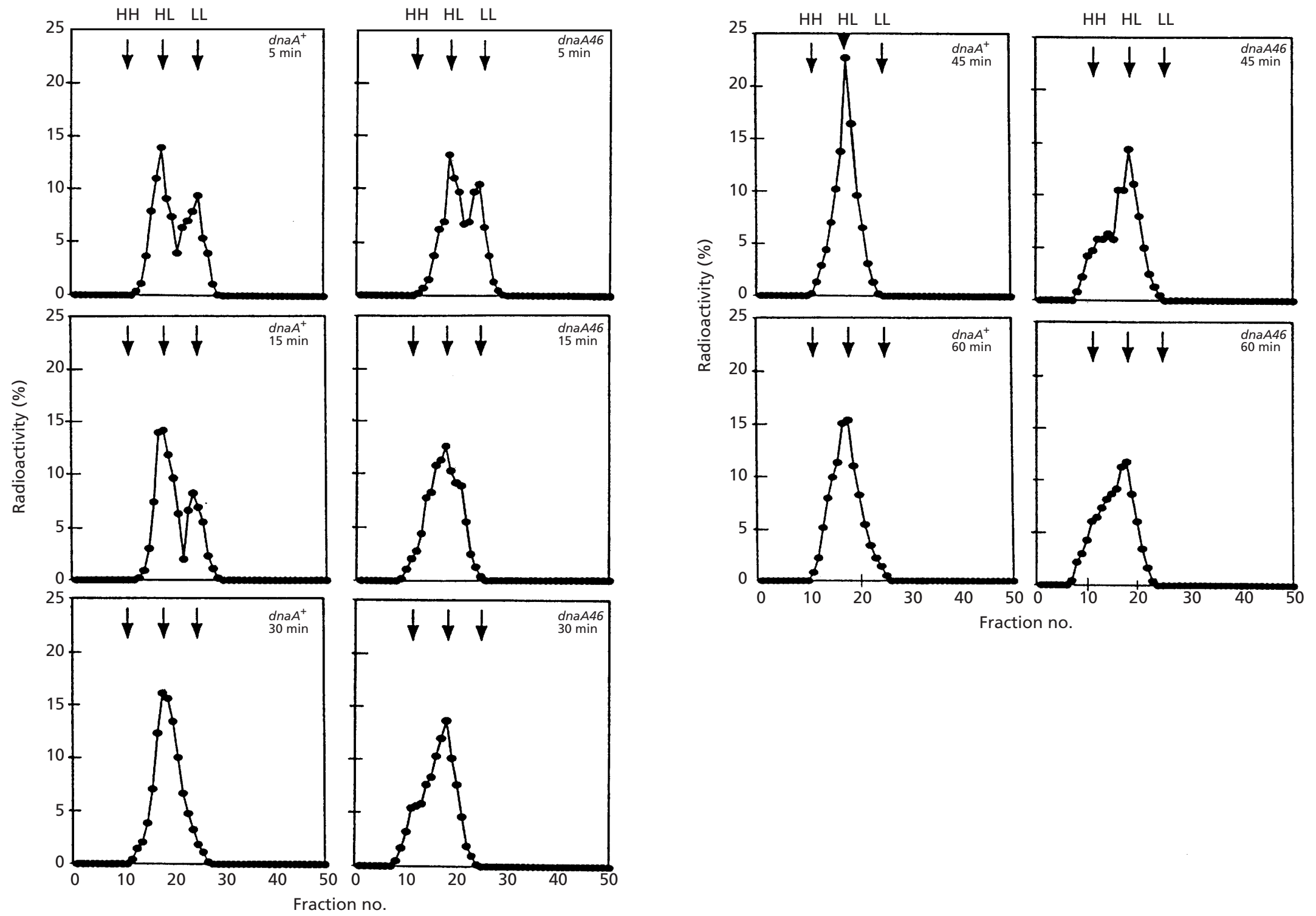

Fig. 3. For legend see facing page 
(b)

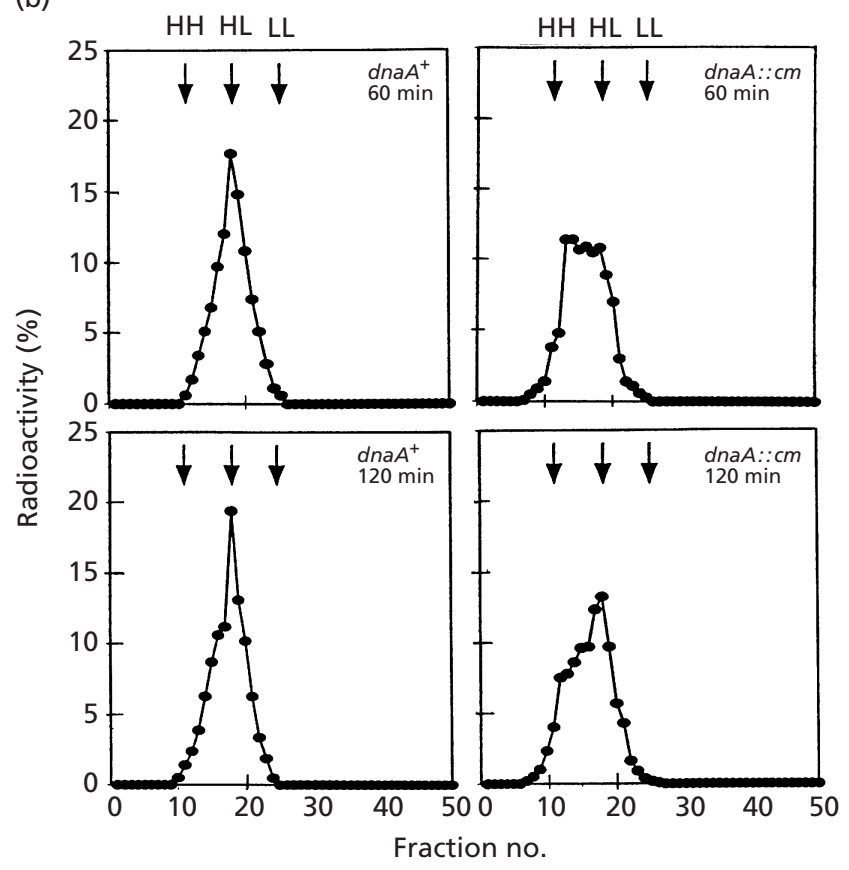

Fig. 3. The fate of DNA of infecting $\lambda$ phage in $E$. coli $d n a A^{+}$ (MG1655) and dnaA46(ts) (BM746) (a), and E. coli dna $A^{+}$ (TC3478) and dnaA:: $\mathrm{cm}$ (BM3477) (b) hosts at $43^{\circ} \mathrm{C}$. Bacteria growing in light medium at $30^{\circ} \mathrm{C}$ were infected with phage 2red3c/857S7 (m.o.i. of 10) labelled with $\left[{ }^{3} \mathrm{H}\right]$ thymidine $\left(8.3 \times 10^{-5}\right.$ c.p.m. p.f.u. $\left.{ }^{-1}\right)$, and further incubation was performed in heavy medium (containing $\left[{ }^{13} \mathrm{C}\right]$ glucose and ${ }^{15} \mathrm{NH}_{4} \mathrm{Cl}$ instead of glucose and $\mathrm{NH}_{4} \mathrm{Cl}$, respectively) at $43{ }^{\circ} \mathrm{C}$. Samples were withdrawn at the indicated times, total DNA was isolated and centrifuged in a $\mathrm{CsCl}$ density gradient. Five-drop fractions were collected from the bottom of the tube and the radioactivity in each fraction was measured in a scintillation counter.

coli laboratory strains which were heavily mutagenized in their long history (G. Wegrzyn et al., 1995b). Since such strains may also contain some as yet unidentified mutations (Glinkowska et al., 1999), we decided to use in most experiments of the present work E. coli wildtype strain MG1655 and its derivatives. In accordance with previous results obtained with different $E$. coli K-12 hosts (G. Węgrzyn et al., 1995b; Sutton \& Kaguni, 1997; Szalewska-Pałasz et al., 1998b) we found that the presence of the $d n a A 46$ (ts) mutation in the MG1655 genetic background allows for normal phage $\lambda$ development at $43{ }^{\circ} \mathrm{C}$ (Fig. 2a). In these experiments we used phage $\lambda c I b 2$, which is able only to grow by the lytic pathway, to avoid a possible influence of lysogenization on the results of our studies concerning the lytic pathway (note that phage DNA replication is also a part of this developmental mode). Analogous experiments performed with phage $\lambda$ red 3 cl857S7 (used in the densityshift experiments; see below) gave very similar results, i.e. no considerable differences between the kinetics of intracellular phage development in the $d n a A^{+}$and dnaA46(ts) host at $43^{\circ} \mathrm{C}$ (data not shown).

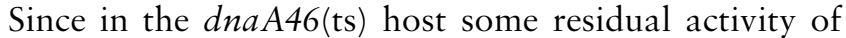
DnaA protein might be retained, we repeated the experiments described above except that a pair of isogenic $d n a A^{+}$and $d n a A$ null $(d n a A:: \mathrm{cm})$ strains were used. Development of phage $\lambda c I b 2$ (Fig. 2b) and phage $\lambda$ red3cI857S7 (data not shown) was not affected by the absence of the dnaA function.

\section{Phage $\lambda$ DNA replication in $E$. coli $d n a A^{+}$and $d n a A$ hosts}

To investigate phage $\lambda$ DNA replication in infected cells we employed density-shift experiments. The cells growing in a light medium were mixed with phage lysate previously labelled with $\left[{ }^{3} \mathrm{H}\right]$ thymidine, and after adsorption the cultivation was continued in a heavy medium. We found that the adsorption efficiency of the phage on both $d n a A^{+}$and $d n a A 46$ (ts) hosts was very similar in these conditions, with a difference below $5 \%$. The fate of parental phage DNA was monitored by isolation of total DNA and ultracentrifugation in a caesium chloride density gradient. The recovery of labelled phage DNA was similar in both strains: $31 \%$ in $d n a A^{+}$and $25 \%$ in $d n a A 46(\mathrm{ts})$, on average. In these experiments we used the $\lambda$ red 3 mutant to impair recombination between phage DNA molecules. When wild-type (MG1655; dnaA ${ }^{+}$) cells were infected, the phage DNA (originally all of it located at the full-light position, data not shown) was found in the full-light (non-replicated molecules) and heavy-light (molecules after at least one replication round) positions 5 and 15 min after infection (Fig. 3a). All radioactivity moved to the heavy-light fractions at $30 \mathrm{~min}$, where it remained until the end of the experiment $(60 \mathrm{~min})$. Since we monitored the fate of parental phage DNA (labelled with $\left[{ }^{3} \mathrm{H}\right]$ thymidine), several rounds of replication proceeding by the $\theta$ mode would result in the shift of radioactivity only to the heavy-light position. At later times after infection $\sigma$ replication intermediates should appear and if parental DNA molecules were to enter this mode of replication, a further shift towards full-heavy position should be observed (total length of $\sigma$ intermediates is up to about ten $\lambda$ genomes; thus, if such a molecule contained one strand of light ${ }^{3} \mathrm{H}$ labelled DNA of the length of one unit of the genome and the rest of the duplex DNA structure were composed of heavy nucleotides, it should be located close to the full-heavy position). However, since on average only a few of about $50 \lambda$ DNA circles that appear due to $\theta$ replication enter rolling-circle replication (see Taylor \& Wegrzyn, 1995), no significant shift towards the full-heavy position was observed (Fig. 3a). Different results were obtained when the dnaA46(ts) bacteria were infected at $43{ }^{\circ} \mathrm{C}$. The shift towards the full-heavy position was already observed 15 min post-infection and it was much more significant at later times (Fig. 3a). This shift strongly suggests that a larger fraction of parental phage DNA molecules enter $\sigma$ replication at this temperature.

The effect of the $d n a A:: \mathrm{cm}$ allele on phage $\lambda$ DNA replication was similar to that of the dnaA46(ts) 
mutation at $43^{\circ} \mathrm{C}$ (Fig. 3b). In these experiments, longer incubation times were employed due to considerably longer generation times of the $r n h d n a A^{+}$and $r n h$ dnaA:: $\mathrm{cm}$ strains relative to MG1655-derived strains. Similar to experiments with the dnaA46(ts) mutant, both the efficiency of phage adsorption and the recovery of parental phage DNA were comparable in $d n a A^{+}$and dnaA null hosts (data not shown).

\section{Phage $\lambda$ DNA synthesis in $E$. coli $d n a A^{+}$and dnaA46(ts) hosts at $43^{\circ} \mathrm{C}$}

The results presented in the preceding paragraphs suggested that contrary to the $\lambda$-infected wild-type host, the early round(s) of replication of phage $\lambda$ DNA in the $d n a A$ mutants may proceed predominantly by the $\sigma$ mode. Therefore, on the basis of the previously proposed model concerning the mechanism of the switch from early to late $\lambda$ DNA replication (Dodson et al., 1986), one may speculate that early after infection of the host devoid of DnaA, $\lambda$ DNA replicates according to the unidirectional $\theta$ mode, which is followed by $\sigma$ replication. To test this hypothesis, we repeated the densityshift experiments except that a non-labelled phage was used. Bacteria growing in the light medium were infected with light phage and further incubation was continued in the heavy medium containing $\left[{ }^{3} \mathrm{H}\right]$ thymidine. Several rounds of $\theta$ replication of the infecting phage genome should lead to the appearance of radioactive DNA at the full-heavy position relatively shortly after infection. Up to $30 \mathrm{~min}$ after the shift from light to heavy medium, one replication round of the host chromosome is possible at most, thus any radioactivity found in the full-heavy fraction must come from newly synthesized $\lambda$ DNA. We determined that under the conditions used in these experiments, incorporation of $\left[{ }^{3} \mathrm{H}\right]$ thymidine into TCAprecipitable material was effective during the first $15 \mathrm{~min}$, and later the efficiency of incorporation dropped significantly (Fig. 4), most probably due to exhaustion of radioactive thymidine. As samples for DNA isolation and density-gradient centrifugation were withdrawn 15 and $30 \mathrm{~min}$ post-infection, radioactivity in the fullheavy fractions observed after the first time interval represented $\lambda$ DNA molecules synthesized according to the $\theta$ mode, and that observed after the second time interval indicated the fate of $\lambda$ DNA already synthesized during the first $15 \mathrm{~min}$ post-infection. We found considerable radioactivity in the full-heavy fractions in samples of the culture of the $\lambda$-infected $d n a A^{+}$host withdrawn $15 \mathrm{~min}$ post-infection (Table 1), indicating that several rounds of $\theta$ replication had occurred. However, low activity was observed in analogous fractions in samples of the culture of the $d n a A 46(t s)$ host infected with $\lambda$ at $43{ }^{\circ} \mathrm{C}$ (Table 1). Therefore, it may be suggested that at most one round of $\theta$ replication was possible in the case of a predominant number of infecting phage DNA molecules. Effective $\lambda$ DNA replication in the dnaA46(ts) mutant during the first $15 \mathrm{~min}$ was confirmed by monitoring the distribution of radioactivity in samples withdrawn 30 min post-infection. Significant radioactivity in the full-heavy fractions was

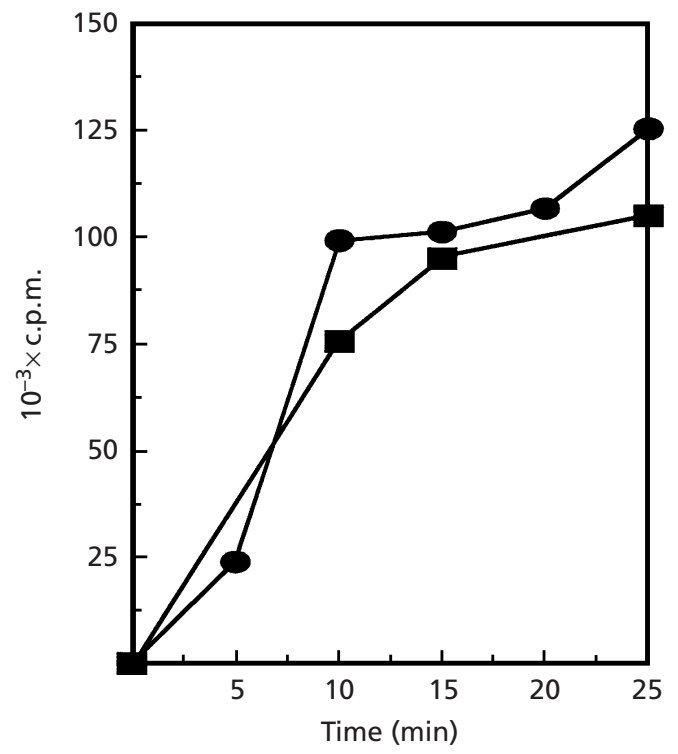

Fig. 4. Incorporation of $\left[{ }^{3} \mathrm{H}\right]$ thymidine $\left(0 \cdot 1 \mathrm{mCi} \mathrm{ml}^{-1}\right)$ into TCAprecipitable material in E. coli $d n a A^{+}$(MG1655; squares) and dnaA46(ts) (BM746; circles) hosts growing in heavy medium at $43^{\circ} \mathrm{C}$.

Table 1. The fate of phage $\lambda$ DNA synthesized during infection of $E$. coli $d n a A^{+}$and $d n a A 46$ (ts) hosts at $43^{\circ} \mathrm{C}$

Bacteria growing in light medium at $30^{\circ} \mathrm{C}$ were infected with phage $\lambda$ red 3 cl857S7 (m.o.i. of 10) and further incubation was performed in heavy medium (containing $\left[{ }^{13} \mathrm{C}\right]$ glucose and ${ }^{15} \mathrm{NH}_{4} \mathrm{Cl}$ instead of glucose and $\mathrm{NH}_{4} \mathrm{Cl}$, respectively) supplemented with $\left[{ }^{3} \mathrm{H}\right]$ thymidine $\left(0 \cdot 1 \mathrm{mCi} \mathrm{ml}^{-1}\right)$ at $43{ }^{\circ} \mathrm{C}$. Samples were withdrawn at the indicated times, total DNA was isolated and centrifuged in a $\mathrm{CsCl}$ density gradient. Five-drop fractions were collected from the bottom of the tube and the radioactivity in each fraction was measured in a scintillation counter. The radioactivity from full-heavy fractions is presented.

\begin{tabular}{|lcc|}
\hline Host* & \multicolumn{2}{c|}{ Radioactivity (c.p.m.) } \\
\cline { 2 - 3 } & 15 min & 30 min \\
\hline dnaA & & 32929 \\
dnaA46 & 32668 & 15710 \\
\hline
\end{tabular}

*E. coli MG1655 (dnaA $A^{+}$and BM746 (dnaA46) strains were used as hosts.

found, perhaps representing $\sigma$ replication intermediates (Table 1). Incorporation of radioactivity into DNA in the heavy-light fractions (mostly E. coli chromosomal DNA) was only slightly lower in the dnaA46(ts) host than in the wild-type strain (15 min post-infection the radioactivity in heavy-light fractions in the sample from the $d n a A 46(\mathrm{ts})$ bacteria was $71 \%$ of that found in the sample from the wild-type bacteria, and 30 min postinfection, the radioactivity in heavy-light fractions in 
(a)

Uni-L

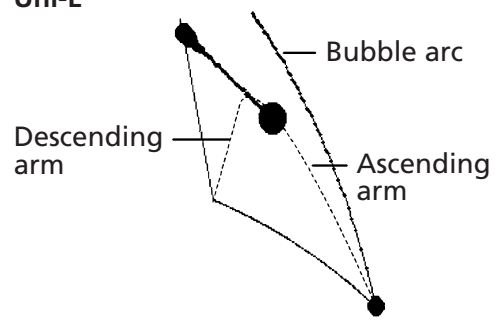

Uni-R

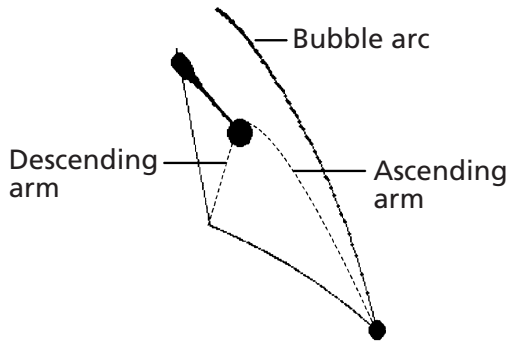

$\mathrm{Bi}$

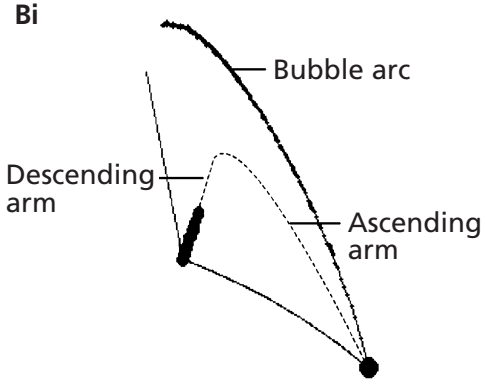

All

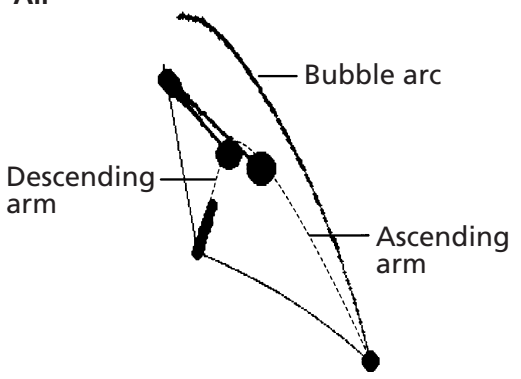

(b)

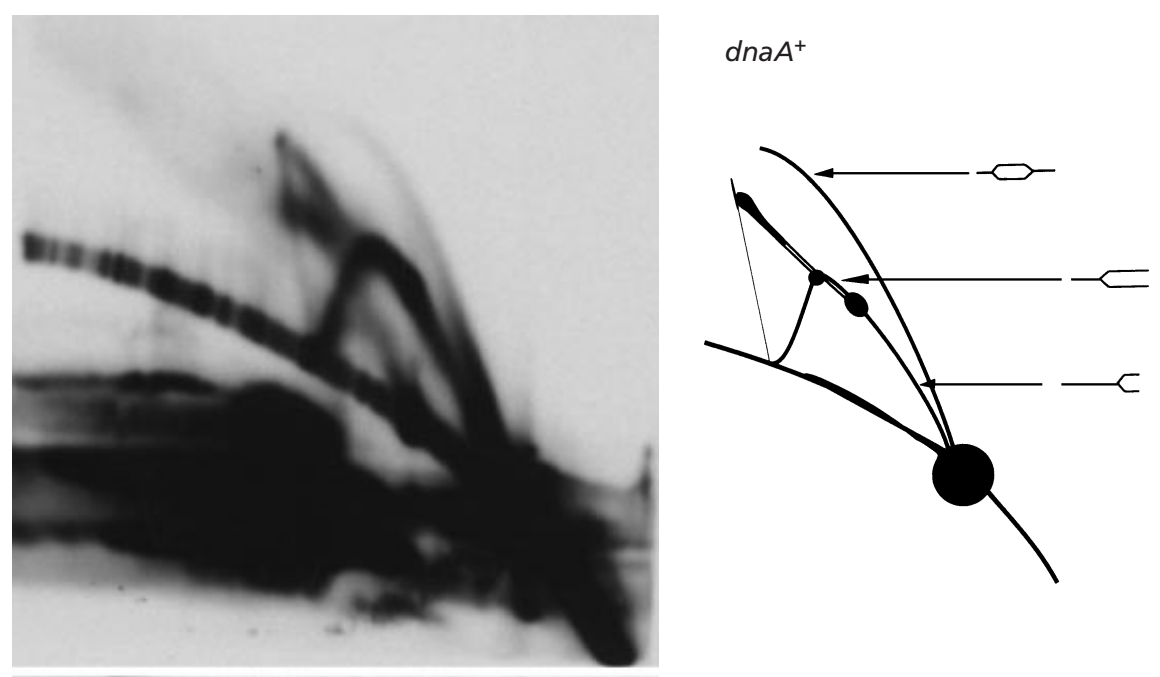

$\operatorname{dna} A 46\left(30^{\circ} \mathrm{C}\right)$

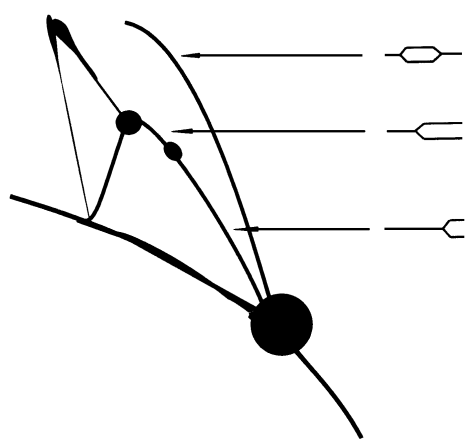

$\operatorname{dna} A 46\left(43^{\circ} \mathrm{C}\right)$

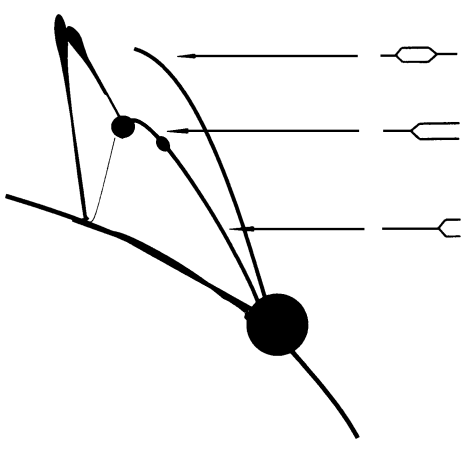

Fig. 5. (a) Theoretical schemes of expected pictures of two-dimensional agarose gel electrophoresis of $\lambda$ plasmid (pKB2 or pKB $2 \pi$ ), digested with HindIII/BamHI, replicating according to unidirectional leftward $\theta$ mode (Uni-L), unidirectional rightward $\theta$ mode (Uni-R), bidirectional $\theta$ mode $(\mathrm{Bi})$ and combination of molecules replicating according to all these modes (All). (b) Results obtained after isolation of plasmid DNA from cultures of $d n a A^{+}$(MG1655) and dnaA46 (BM746) hosts bearing $\mathrm{PKB} 2$ or $\mathrm{pKB} 2 \pi$ and growing at different temperatures. 

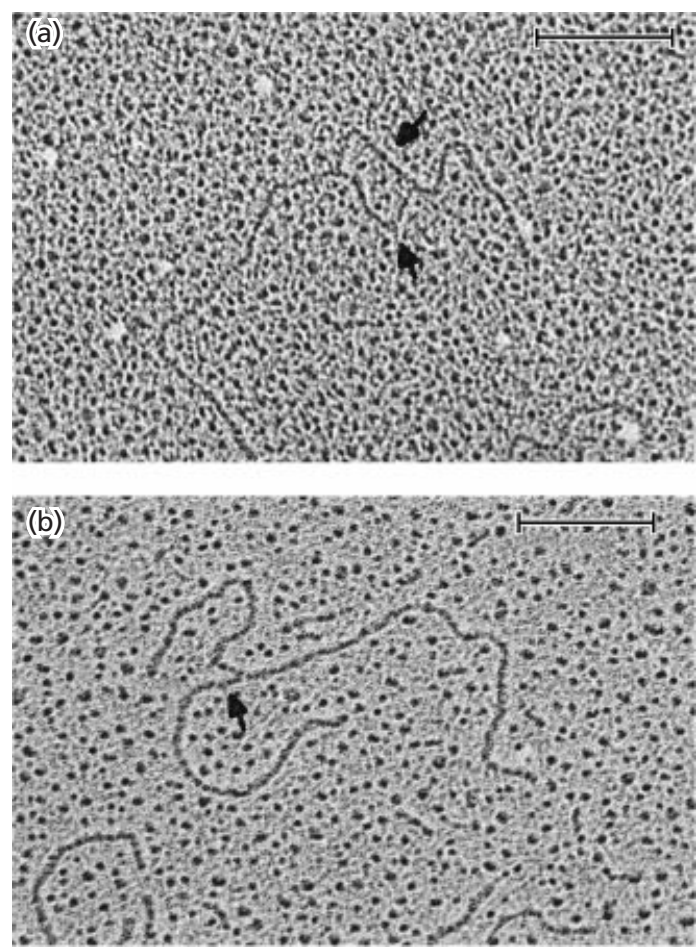

Fig. 6. Examples of electron microscopy analysis of $\lambda$ plasmid (pKB2 or pKB2 $\pi$ ) replication intermediates. Plasmid molecules were isolated from E. coli cells, digested with HindIII/BamHI, prepared for electron microscopy, and analysed by measuring lengths of replication bubbles and/or arms in bubble-containing and Y-shaped replication intermediates. For determination of the directionality of replication, the known position of ori $\lambda$ was assumed as the only possible replication start point. Examples of bidirectionally replicating molecule (a) and unidirectionally replicating molecule (b) are presented (positions of ori $\lambda$ s are indicated by arrows). Bars, $250 \mathrm{~nm}$.

the sample from the $d n a A 46(\mathrm{ts})$ bacteria was $86 \%$ of that found in the sample from the wild-type bacteria). Moreover, we observed no shift of radioactivity to the full-heavy position in analogous samples from noninfected cultures (data not shown).

Despite the fact that some other possible (though, in our opinion, less likely) explanations of the data presented above could be provided, these results are still compatible with the hypothesis that in the absence of DnaA function $\lambda$ DNA replicates predominantly according to the unidirectional $\theta$ mode, and after one round of such replication switches to the $\sigma$ mode. Thus, the next step in our studies was to test the directionality of $\lambda$ DNA replication in the presence and absence of DnaA function.

\section{Directionality of $\theta$ replication of $\lambda$ DNA analysed by two-dimensional agarose gel electrophoresis}

Plasmids derived from bacteriophage $\lambda$ (referred to as $\lambda$ plasmids) contain all the genes and regulatory sequences necessary for autonomous replication in E. coli. These plasmids replicate in the host cells by the $\theta$ mode (for reviews see Taylor \& Węgrzyn, 1995, 1998). Therefore, we used the $\lambda$ plasmids in studies on the directionality of $\theta$ replication of $\lambda$ DNA in $d n a A^{+}$and $d n a A 46$ (ts) strains. Wild-type $\lambda$ plasmids cannot be maintained in certain $d n a A(t s)$ mutants (including dnaA46) even at $30^{\circ} \mathrm{C}$, but derivatives bearing a mutation of the $\pi$ type in the $\lambda P$ gene can (Kur et al., 1987; Węgrzyn et al., 1996). Thus, in experiments with a $d n a A 46$ (ts) host we used the $\pi$ mutant plasmid. Since it was demonstrated previously that even $\lambda \pi$ plasmids can perform only one replication round in the dnaA46(ts) host after a shift from $30^{\circ} \mathrm{C}$ to $43{ }^{\circ} \mathrm{C}$ (Kur et al., 1987), we isolated plasmid DNA for two-dimensional agarose gel electrophoresis analysis 15 min after the temperature shift.

We used E. coli nnaA $^{+}$and $d n a A 46$ (ts) hosts bearing plasmids $\mathrm{pKB} 2$ and $\mathrm{pKB} 2 \pi$, respectively. Following isolation, these plasmids were digested with different restriction enzymes (shown in Fig. 1b) and analysed by two-dimensional agarose gel electrophoresis. Theoretical patterns of $\lambda$ plasmid replication intermediates in the case of bidirectional and unidirectional (leftward and rightward) replication in samples digested with HindIII and BamHI, predicted by a computer method assuming that replication forks initiate synchronously and travel at the same rate (Viguera et al., 1998), are presented in Fig. 5(a). The results obtained and their interpretation are presented in Fig. 5(b). In the $d n a A^{+}$ host, replication of wild-type $\lambda$ plasmid (pKB2) proceeds both bidirectionally and unidirectionally. Bidirectional replication is represented by the characteristic shape of the bubble arc and the intensive descending arm of the simple-Y arc. The dots at the top and at the ascending arm of the simple-Y arc suggest rightward and leftward unidirectional replication, respectively. No significant differences in the pattern of replication intermediates were observed between DNA samples isolated from dna $A^{+} / \mathrm{pKB} 2$ bacteria growing at different temperatures: $30^{\circ} \mathrm{C}, 37^{\circ} \mathrm{C}$ or $43^{\circ} \mathrm{C}$ (data not shown). Similar to the wild-type plasmid in the $d n a A^{+}$host, replication of pKB $2 \pi$ in dnaA46 cells at $30^{\circ} \mathrm{C}$ proceeds both bidirectionally and unidirectionally. In the case of unidirectional replication, the intermediates of both leftward and rightward replication were detected. Thus, the presence of the $\pi$ mutation in the plasmid and dnaA46(ts) mutation in the host genome has no significant influence on the directionality of plasmid replication at $30^{\circ} \mathrm{C}$. However, analysis of pKB $2 \pi$ replication intermediates isolated from the $d n a A 46(\mathrm{ts})$ mutant growing at $43{ }^{\circ} \mathrm{C}$ revealed that bidirectional replication was less frequent relative to that observed at $30^{\circ} \mathrm{C}$ as the descending arm of the simple-Y arc is considerably less intensive.

In conclusion, replication of $\lambda$ plasmids in $E$. coli cells proceeds both bidirectionally and unidirectionally, but in the absence of $d n a A$ function (dnaA46 mutant at $43^{\circ} \mathrm{C}$ ) the bidirectional replication seems to be less frequent. This was also confirmed during the analysis of replication intermediates after digestion of plasmid DNA with other restriction enzymes: BglII and SalI, EcoRV and SalI, and NdeI (data not shown). 
Table 2. Electron microscopy analysis of the directionality of $\lambda$ plasmid replication

E. coli MG1655 $\left(d n a A^{+}\right)$and BM746 (dnaA46) strains were used as hosts. Plasmids pKB2 and pKB2 $\pi$ (in the dnaA46 host) were investigated. About $100 \mathrm{Y}$-shaped or bubble-containing plasmid fragments (HindIII-BamHI fragments bearing ori $\lambda$ ) were analysed in each sample. Only the molecules of the expected lengths were considered. Since in a population of $\lambda$ plasmid molecules isolated from E. coli cells there are both monomers and multimers, in the latter case replication initiated from one origin enters another replication region and may give ambiguous results. Therefore, only DNA fragments revealing clear features of unidirectional or bidirectional replication initiated from orid present in the same fragment were considered. Among unidirectionally replicating molecules, in all cases the distribution between rightward and leftward replication intermediates was roughly equal (data not shown).

\begin{tabular}{|lcccc|}
\hline Replication mode & \multicolumn{4}{c|}{$\begin{array}{c}\text { Replication intermediates in } \\
\text { E. coli hosts (\%) }\end{array}$} \\
\cline { 2 - 5 } & $\begin{array}{c}d n a A^{+} \\
\left(30^{\circ} \mathrm{C}\right)\end{array}$ & $\begin{array}{c}d n a A^{+} \\
\left(43^{\circ} \mathrm{C}\right)\end{array}$ & $\begin{array}{c}d n a A 46 \\
\left(30^{\circ} \mathrm{C}\right)\end{array}$ & $\begin{array}{c}d n a A 46 \\
\left(43^{\circ} \mathrm{C}\right)\end{array}$ \\
\hline Bidirectional $\theta$ & 36 & 34 & 40 & 11 \\
Unidirectional $\theta$ & 64 & 66 & 60 & 89 \\
\hline
\end{tabular}

\section{Electron microscopic analysis of the directionality of $\theta$ replication of $\lambda$ DNA}

Two-dimensional agarose gel electrophoresis demonstrated that an impaired DnaA function may result in less frequent bidirectional replication of $\lambda$ plasmid DNA. To obtain quantitative data, we analysed plasmid molecules (isolated as for two-dimensional agarose gel electrophoresis) using electron microscopic techniques. Plasmid DNA molecules isolated from $d n a A^{+}$or dnaA46(ts) bacteria were cut with HindIII and BamHI (see Fig. 1b) and analysed by electron microscopy. Fragments of molecules containing bubbles as well as Yshaped DNA fragments were identified and the lengths of appropriate arms were measured. For determination of the directionality of replication, the known position of orid was assumed to be the only possible replication start point (Fig. 6). Thus, we could determine the fraction of bidirectionally and unidirectionally replicating plasmids. We found that in the $d n a A^{+}$host about $40 \%$ of $\lambda$ plasmid molecules replicate bidirectionally irrespective of temperature (Table 2). A similar distribution of plasmid replication intermediates was found in the dnaA46(ts) mutant growing at $30^{\circ} \mathrm{C}$, confirming the conclusion based on two-dimensional agarose gel analysis that combination of $\pi$ and $d n a A 46$ (ts) mutations has little effect on directionality of $\lambda$ plasmid replication at this temperature. However, among all replication intermediates found in dnaA46(ts) bacteria at $43^{\circ} \mathrm{C}$, only about $10 \%$ were derived from bidirectionally replicating plasmids (Table 2). These results are in agreement with our conclusion, based on data from two-dimensional agarose gel electrophoresis, that bi-
Table 3. Electron microscopic analysis of directionality of pTC $\lambda 1$ plasmid replication in E. coli dnaA46(ts) mutant

\begin{tabular}{|lcc|}
\hline Replication mode & \multicolumn{2}{c|}{ Replication intermediates $(\%)^{*}$} \\
\cline { 2 - 3 } & $\mathbf{3 0}{ }^{\circ} \mathrm{C}$ & $\mathbf{4 3}{ }^{\circ} \mathrm{C}$ \\
\hline Bidirectional $\theta$ & 46 & 40 \\
Unidirectional $\theta$ & 54 & 60 \\
\hline
\end{tabular}

*For experimental details see legend to Table 2. Among unidirectionally replicating molecules, in all cases the distribution between rightward and leftward replication intermediates was roughly equal (data not shown).

directional DNA replication from orid is impaired in the absence of functional DnaA.

\section{DnaA affects the directionality of replication from orid by acting on the $p_{\mathrm{R}}$ promoter}

The results described above indicated that the $d n a A$ gene product affects the directionality of replication from orid directly or indirectly. Since it was demonstrated previously that DnaA directly stimulates transcription from the $\lambda p_{\mathrm{R}}$ promoter (Szalewska-Pałasz et al., 1998a), whose activity is necessary for transcriptional activation of ori $\lambda$, we asked whether this direct DnaA-mediated regulation is responsible for the observed effects of the dnaA46(ts) mutation on the replication from ori $\lambda$. Thus, we investigated replication of an artificial $\lambda$ plasmid called pTC $\lambda 1$, which bears the $p_{\text {tet }}$ promoter instead of $p_{\mathrm{R}}$ (Herman-Antosiewicz et al., 1998a). DnaA-independence of activity of the $p_{\text {tet }}$ promoter has been demonstrated previously (HermanAntosiewicz et al., 1998b). Using both two-dimensional agarose gel electrophoresis (data not shown) and electron microscopy (Table 3 ) we found that inactivation of the $d n a A$ gene product has little effect on the directionality of pTC $\lambda 1$ replication (Table 3 ). Since the only considerable difference between pTC $\lambda 1$ and standard $\lambda$ plasmid replicons is in the kind of promoter located upstream of ori $\lambda$, we conclude that DnaA affects the directionality of natural $\lambda$ replicons by acting on the $p_{\mathrm{R}}$ promoter.

\section{DISCUSSION}

\section{A role for the host-encoded DnaA protein in the regulation of the switch from $\theta$ to $\sigma$ DNA replication of bacteriophage $\lambda$}

Upon infection of its E. coli host, replication of bacteriophage $\lambda$ DNA proceeds according to the $\theta$ mode and is then switched to $\sigma$ mode (reviewed by Taylor \& Węgrzyn, 1995, 1998). Dodson et al. (1986) proposed that $\sigma$ replication may be preceded by one round of unidirectional $\theta$ replication initiated at ori followed by displacement of the $5^{\prime}$ end of the newly synthesized 


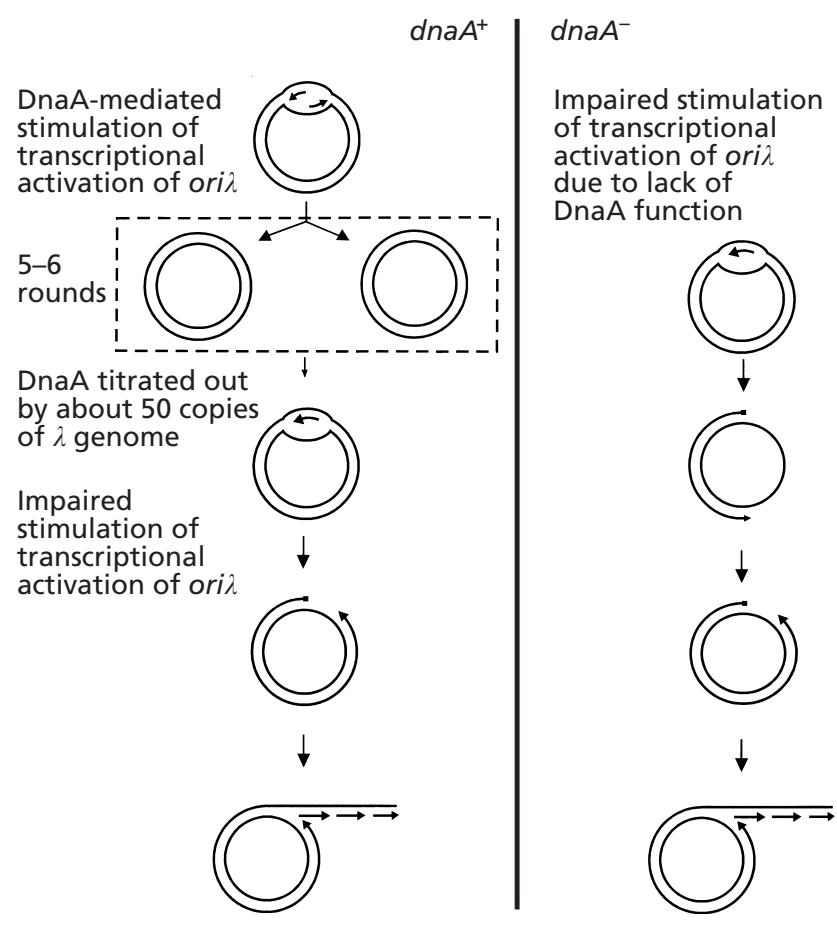

Fig. 7. A model for the regulation of the switch from $\theta$ to $\sigma$ replication of phage $\lambda$ genome in wild-type bacteria (left panel) and in $d n a A$ mutants (right panel). In a wild-type host, DnaAmediated stimulation of transcriptional activation of ori $\lambda$ allows for initiation of bidirectional $\theta$ replication of $\lambda$ DNA. After five to six rounds of replication, about 50 copies of the $\lambda$ genome appear. Due to presence of many DnaA binding sequences in $\lambda$ DNA, cellular DnaA protein is titrated out and transcriptional activation of ori $\lambda$ becomes significantly less efficient. This leads to the initiation of unidirectional $\theta$ replication, which after one round switches to the $\sigma$ mode according to the mechanism previously described by Dodson et al. (1986), who proposed that a round of unidirectional $\theta$ replication initiated at ori $\lambda$ is followed by displacement of the $5^{\prime}$ end (dot) of the newly synthesized leading strand by its growing $3^{\prime}$ end (arrow). In a $\lambda$ infected $d n a A$ mutant, due to impaired stimulation of the $p_{R}$ promoter, unidirectional $\theta$ replication starts shortly after infection which results in the appearance of $\sigma$ replication intermediates considerably earlier than in the wild-type host. For simplification of the diagram (in both panels), at the switch from $\theta$ to $\sigma$ replication only the fate of the parental strand directing the synthesis of the leading strand is shown. However, one should note that there is still another copy of $\lambda$ DNA after a round of replication (the copy formed due to synthesis of the lagging strand that is not shown in the diagram), which can initiate following replication round(s).

leading strand by its growing 3 ' end (Fig. 7). However, the precise mechanism regulating this switch is still not known. To find factor(s) responsible for this regulation we focused our attention on proteins that could potentially be involved in the control of directionality of DNA replication initiated at ori $\lambda$. It was previously demonstrated using an in vitro system reconstituted from purified proteins that replication of $\lambda$ DNA proceeds unidirectionally in the absence of transcription, but a significant fraction of molecules replicate bidirectionally after the addition of RNA polymerase (Learn et al., 1993). The only transcription which is absolutely necessary for $\lambda$ DNA replication in vivo and can be involved in $\lambda$ DNA replication in vitro seems to be that initiated at the $p_{\mathrm{R}}$ promoter. This promoter is stimulated by the host DnaA protein (G. Weegrzyn et al., 1995a, Szalewska-Pałasz et al., 1998a). Therefore, we investigated replication of phage $\lambda$ DNA in dnaA mutants.

Our density-shift experiments suggested that in the absence of functional DnaA, a large fraction of parental phage $\lambda$ DNA molecules enters $\sigma$ replication shortly after infection. These results confirmed the previously reported electron microscopic observations that $\sigma$ replication intermediates appear in $\lambda$-infected $d n a A$ mutant cells as soon as 5 min post-infection (G. Weegrzyn et al., 1995b; Konopa et al., 2000). In those studies, a $\lambda$ phage bearing the mutated $P$ gene and E. coli hosts bearing multiple mutations (apart from dnaA46) were used (G. Wegrzyn et al., 1995b; Konopa et al., 2000). Here, we demonstrate that our previous results are very similar to those obtained with a host with a wild-type genetic background and $\lambda P^{+}$phages. In fact, using electron microscopy we were able to observe $\sigma$ replication intermediates early after infection of the strain BM764 (MG1655-derived dnaA46 mutant) by $\lambda P^{+}$phage, similar to the results reported previously with more complex genetic backgrounds (G. Węgrzyn et al., 1995b; Konopa et al., 2000 and our unpublished results).

By analysis of replication initiated at ori using two dimensional agarose gel electrophoresis and electron microscopy, we demonstrated that while in the wild-type host and in the dnaA46(ts) mutant at $30^{\circ} \mathrm{C}$ bidirectional replication is frequent, in the dnaA46(ts) host at $43{ }^{\circ} \mathrm{C}$ it is predominantly unidirectional. Since replacement of the $p_{\mathrm{R}}$ promoter with $p_{\text {tet }}$ (whose activity is not dependent on DnaA) resulted in abolition of the effect of the $d_{n a A}$ mutation on the replication directionality, we conclude that DnaA acts in the control of directionality of replication from orid by regulation of transcription initiated at $p_{\mathrm{R}}$.

\section{Model for regulation of the switch from $\theta$ to $\sigma$ DNA replication}

Transcription initiated at the $p_{\mathrm{R}}$ promoter and proceeding near or through orid is called transcriptional activation of ori $\lambda$. This process has been known for a long time (Dove et al., 1969; Nijkamp et al., 1971) to be necessary for $\lambda$ DNA replication in vivo, but its exact role was unclear until recently. The results presented in this paper, together with previously reported observations (Learn et al., 1993; G. Węgrzyn et al., 1995b, 1996), indicate that transcriptional activation of orid is necessary for initiation of bidirectional replication from this region. This led us to propose a mechanism of regulation of the switch from $\theta$ to $\sigma$ replication of bacteriophage $\lambda$ DNA. Since DnaA positively regulates transcription from the $p_{\mathrm{R}}$ promoter (Szalewska-Pałasz et al., 1998a), its activity is necessary for frequent initiation of bidirectional replication from orid in E. coli. Early after infection, in spite of the presence of many 
DnaA boxes in the E. coli chromosome, there is a sufficient concentration of free DnaA molecules in the cell to stimulate bidirectional $\theta$ replication, as maximal activation of $p_{R}$ by DnaA occurs at relatively low concentrations of this protein (Szalewska-Pałasz et al., 1998a). However, after a few rounds of bidirectional $\theta$ replication, many copies of the $\lambda$ genome appear (about 50 copies after five to six replication rounds). Since it was previously demonstrated by Szalewska-Pałasz et al. (1998c) that there are many DnaA binding sites in $\lambda$ DNA, the DnaA protein may be titrated out. This should lead to an inefficient transcriptional activation of ori $\lambda$ resulting in unidirectional $\theta$ replication followed by the $\sigma$ replication mode. In $d n a A$ mutants, weak transcription from the $p_{\mathrm{R}}$ promoter allows predominantly unidirectional $\theta$ replication and a switch to $\sigma$ replication shortly after infection. This model is presented schematically in Fig. 7. If this model is correct, the DnaA box sequences responsible for titrating out DnaA molecules after several rounds of bidirectional $\theta$ replication of the $\lambda$ genome in the wild-type host should be of weak affinity to this protein. This would allow efficient transcriptional activation of orid and bidirectional $\theta$ replication at the beginning of the infection cycle. In accordance with this prediction, it was reported that most DnaA boxes present in the $\lambda$ genome are weak ones (Szalewska-Pałasz et al., 1998c).

Better \& Freifelder (1983) reported that $\sigma$ replication intermediates can be also occasionally found at early times after infection of wild-type hosts by $\lambda$ phage. They found that $\theta$ replication is predominant, but not exclusive, at early stages of infection and $\sigma$ replication is predominant, but not exclusive, at late stages of infection. This is also compatible with the results presented in this report and with our model of the switch from $\theta$ to $\sigma$ replication, as we have demonstrated that in the presence of DnaA function the replication of $\lambda$ plasmids proceeds bidirectionally and unidirectionally, and in the absence of DnaA function the replication is predominantly, but not exclusively, unidirectional. In fact, after inactivation of DnaA we observed (using electron microscopy) a decrease in the fraction of bidirectionally replicating $\lambda$ DNA from $40 \%$ to $10 \%$, whereas the dnaA46(ts) mutation at $43{ }^{\circ} \mathrm{C}$ was responsible for a huge increase in $\sigma$-type replication intermediates as revealed by density-shift experiments. However, one should note that the electron microscopy studies were performed with plasmids occurring in many copies per cell, whereas in the density shift experiments only a few phages infected one cell. Moreover, whole population of $\lambda$ plasmid molecules was investigated by electron microscopy, whereas the fate of only parental phage $\lambda$ DNA molecules was monitored in density-shift experiments.

\section{A physiological role for the switch from $\theta$ to $\sigma$ DNA replication}

It is also interesting to consider a physiological role for a DnaA-regulated switch from $\theta$ to $\sigma$ replication of phage $\lambda$ DNA. Since efficient growth of $\lambda$ phage was observed in the $d n a A 46$ (ts) mutant at $43{ }^{\circ} \mathrm{C}$, i.e. under conditions in which $\sigma$ replication starts early after infection, it raises the question as why should $\theta$ replication occur at early stages of infection in a wildtype host? The physiological role of $\theta$ replication should be the production of many copies of $\lambda$ DNA to be used as templates for high level of expression of phage genes employed during lytic development. If this is true, the amount of $\lambda$ DNA produced by $\sigma$ replication is high enough for expression of phage proteins in amounts sufficient to support normal lytic development. However, it is worth noting that studies on $\lambda$ development, which demonstrated efficient production of phage progeny in dnaA mutants (G. Węgrzyn et al., 1995b; Sutton \& Kaguni, 1997; Szalewska-Pałasz et al., 1998b; Glinkowska et al., 1999; this work), were carried out under standard laboratory conditions (i.e. in LB medium with good aeration, etc.) that support high E. coli growth rates. It was demonstrated recently that under these conditions, in a wild-type host, phage $\lambda$ produces at least some proteins in excess of those needed for its effective propagation: thus efficient growth of the phage may be achieved even under less favourable conditions (Gabig et al., 1998). This phage developmental strategy may be responsible for efficient $\lambda$ growth in dnaA mutants, in which expression of phage genes is expected to be decreased relative to the wild-type host. If this is true, one might expect an inhibition of $\lambda$ lytic development in a $d n a A$ mutant growing in poor media. Indeed, it has been reported that phage $\lambda$ lytic growth is less efficient in wild-type cells cultivated in minimal media, and it may be completely inhibited in slowly growing dnaA46(ts) mutants at $43{ }^{\circ} \mathrm{C}$ (Węgrzyn et al., 2000).

\section{ACKNOWLEDGEMENTS}

We acknowledge the invaluable contribution of Karol Taylor at the beginning of this project. We thank Joanna Potrykus and Katarzyna Potrykus for critical reading of the manuscript. This work was supported by the USA-Poland Maria Sklodowska-Curie Joint Fund II (grant MEN/HHS-96-255), the Polish State Committee for Scientific Research (project 6 P04A 016 16), the Volkswagen Foundation (grant I/74 639), the University of Gdańsk (grant BW/1190-5-0145-9), the Spanish Dirección General de Enseñanza Superior (grant PM95/0016), the Spanish Fondo de Investigación Sanitaria (grant 96/0470) and the Comunidad de Madrid (grant 08.6/0016/1997). We acknowledge financing of a short term fellowship of S. B. in the CSIC (Madrid) by EMBO (award no. ASTF9021). G. W. acknowledges also financial support from the Foundation for Polish Science (subsydium 14/2000).

\section{REFERENCES}

Alfano, C. \& McMacken, R. (1989a). Ordered assembly of nucleoprotein structures at the bacteriophage $\lambda$ replication origin during the initiation of DNA replication. J Biol Chem 264, 10699-10708.

Alfano, C. \& McMacken, R. (1989b). Heat shock protein-mediated disassembly of nucleoprotein structures is required for the initiation of bacteriophage $\lambda$ DNA replication. J Biol Chem 264, 10709-10718. 
Better, M. \& Freifelder, D. (1983). Studies on the replication of Escherichia coli phage $\lambda$ DNA. Virology 126, 168-182.

Burkardt, H. \& Lurz, R. (1984). Electron microscopy. In Advanced Molecular Genetics, pp. 281-313. Edited by A. Puhler \& K. N. Timmis. Berlin and Heidelberg: Springer.

Dodson, M., Echols, H., Wickner, S., Alfano, C., Mensa-Wilmot, K., Gomes, B., LeBowitz, J., Roberts, J. D. \& McMacken, R. (1986). Specialized nucleoprotein structures at the origin of replication of bacteriophage $\lambda$ : localized unwinding of duplex DNA by a six protein reaction. Proc Natl Acad Sci US A 83, 7638-7642.

Dove, W. F., Hargrove, E., Ohashi, M., Haugli, F. \& Guha, A. (1969). Replicator activation in lambda. Jpn J Genet 44 (Suppl. 1), 11-22.

Gabig, M., Obuchowski, M., Weegrzyn, A., Szalewska-Pałasz, A., Thomas, M. S. \& Wegrzyn, G. (1998). Excess production of phage $\lambda$ delayed early proteins under conditions supporting high Escherichia coli growth rates. Microbiology 144, 2217-2224.

Glinkowska, M., Węgrzyn, A. \& Węgrzyn, G. (1999). Replication of bacteriophage $\lambda$ in the Escherichia coli dnaA $\Delta$ rac hosts. Genetics 151, 1633-1635.

Gottesman, M. (1999). Bacteriophage $\lambda$ : the untold story. J Mol Biol 293, 177-180.

Herman-Antosiewicz, A., Śrutkowska, S., Taylor, K. \& Węgrzyn, G. (1998a). Replication and maintenance of $\lambda$ plasmids devoid of the Cro repressor autoregulatory loop in Escherichia coli. Plasmid 40, 113-125.

Herman-Antosiewicz, A., Węgrzyn, A., Taylor, K. \& Węgrzyn, G. (1998b). DnaA-mediated regulation of phage $\lambda$-derived replicons in the absence of $p_{R}$ and Cro function. Virology 249, 98-107.

Ingmer, H. \& Atlung, T. (1992). Expression and regulation of a dnaA homologue isolated from Pseudomonas putida. Mol Gen Genet 232, 431-439.

Jensen, K. F. (1993). The Escherichia coli 'wild types' W3110 and MG1655 have an $r p h$ frameshift mutation that leads to pyrimidine starvation due to low pyrE expression levels. J Bacteriol 175, 3401-3407.

Konopa, G., Barańska, S., Węgrzyn, A. \& Węgrzyn, G. (2000). Bacteriophage and host mutants causing the rolling-circle $\lambda$ DNA replication early after infection. FEBS Lett 472, 217-220.

Kornberg, A. \& Baker, T. A. (1992). DNA Replication. New York: W. H. Freeman.

Kur, J., Górska, I. \& Taylor, K. (1987). Escherichia coli dnaA initiation function is required for replication of plasmids derived from coliphage lambda. J Mol Biol 198, 203-210.

Learn, B., Karzai, A. W. \& McMacken, R. (1993). Transcription stimulates the establishment of bidirectional $\lambda$ DNA replication in vitro. Cold Spring Harbor Symp Quant Biol 58, 389-402.

Mensa-Wilmot, K., Seaby, R., Alfano, C., Wold, M. S., Gomes, B. \& McMacken, R. (1989). Reconstitution of a nine-protein system that initiates bacteriophage $\lambda$ DNA replication. J Biol Chem 264 , 2853-2861.

Nijkamp, H. J. J., Szybalski, W., Ohashi, M. \& Dove, W. F. (1971). Gene expression by constitutive mutants of coliphage lambda. Mol Gen Genet 114, 80-88.

Schnos, M. \& Inman, R. B. (1970). Position of branch point in replicating $\lambda$ DNA. J Mol Biol 51, 61-73.

Singer, M., Baker, T. A., Schnitzler, G. \& 7 other authors (1989). A collection of strains containing genetically linked alternating antibiotic resistance elements for genetic mapping of Escherichia coli. Microbiol Rev 53, 1-24.

Śrutkowska, S., Konopa, G. \& Węgrzyn, G. (1998). A method for isolation of plasmid DNA replication intermediates from unsynchronized bacterial cultures for electron microscopy analysis. Acta Biochim Pol 45, 233-240.

Śrutkowska, S., Caspi, R., Gabig, M. \& Węgrzyn, G. (1999). Detection of DNA replication intermediates after two-dimensional agarose gel electrophoresis using a fluorescein-labeled probe. Anal Biochem 269, 221-222.

Stillman, B. (1994). Initiation of chromosomal DNA replication in eukaryotes: lessons from lambda. J Biol Chem 269, 7047-7050.

Subak-Sharpe, J. H. \& Dargan, D. J. (1998). HSV molecular biology: general aspects of Herpes Simplex Virus molecular biology. Virus Genes 16, 239-251.

Sutton, M. D. \& Kaguni, J. M. (1997). Novel alleles of the Escherichia coli dnaA gene. J Mol Biol 271, 693-703.

Szalewska-Pałasz, A., Węgrzyn, A., Błaszczak, A., Taylor, K. \& Wegrzyn, G. (1998a). DnaA-stimulated transcriptional activation of orid: Escherichia coli RNA polymerase $\beta$ subunit as a transcriptional activator contact site. Proc Natl Acad Sci U S A 95, 4241-4246.

Szalewska-Pałasz, A., Lemieszek, E., Pankiewicz, A., Węgrzyn, A., Helinski, D. R. \& Węgrzyn, G. (1998b). Escherichia coli dnaA gene function and bacteriophage $\lambda$ replication. FEMS Microbiol Lett $167,27-32$.

Szalewska-Pałasz, A., Weigel, C., Speck, C. \& 7 other authors (1998c). Interaction of the Escherichia coli DnaA protein with bacteriophage $\lambda$ DNA. Mol Gen Genet 259, 679-688.

Taylor, K. \& Węgrzyn, G. (1995). Replication of coliphage lambda DNA. FEMS Microbiol Rev 17, 109-119.

Taylor, K. \& Węgrzyn, G. (1998). Regulation of bacteriophage $\lambda$ replication. In Molecular Microbiology, pp. 81-97. Edited by S. J. W. Busby, C. M. Thomas \& N. L. Brown. Berlin and Heidelberg: Springer.

Thomas, R. (1993). Bacteriophage $\lambda$ : transactivation, positive control and other odd findings. BioEssays 15, 285-289.

Viguera, E., Hernandez, P., Krimer, D. B., Boistov, A. S., Lurz, R., Alonso, J. C. \& Schvartzman, J. B. (1996). The ColE1 unidirectional origin acts as a polar replication fork pausing site. J Biol Chem 271, 22414-22421.

Viguera, E., Rodríguez, A., Krimer, D. B., Hernández, P., Trelles, O. \& Schvartzman, J. B. (1998). A computer model for the analysis of DNA replication intermediates by two-dimensional (2D) agarose gel electrophoresis. Gene 217, 41-49.

Wegrzyn, A., Węgrzyn, G. \& Taylor, K. (1995a). Protection of coliphage $\lambda \mathrm{O}$ initiator protein from proteolysis in the assembly of the replication complex in vivo. Virology 207, 179-184.

Węgrzyn, A., Węgrzyn, G. \& Taylor, K. (1995b). Plasmid and host functions required for $\lambda$ plasmid replication carried out by the inherited replication complex. Mol Gen Genet 247, 501-508.

Węgrzyn, A., Czyż, A., Gabig, M. \& Wegrzyn, G. (2000). $\mathrm{ClpP} / \mathrm{ClpX}$-mediated degradation of the bacteriophage $\lambda \mathrm{O}$ protein and regulation of $\lambda$ phage and $\lambda$ plasmid replication. Arch Microbiol 174, 89-96.

Węgrzyn, G., Kwásnik, E. \& Taylor, K. (1991). Replication of $\lambda$ plasmid in amino acid-starved strains of Escherichia coli. Acta Biochim Pol 38, 181-186.

Węgrzyn, G., Szalewska-Pałasz, A., Węgrzyn, A., Obuchowski, M. \& Taylor, K. (1995a). Transcriptional activation of the origin of coliphage $\lambda$ DNA replication is regulated by the host DnaA initiator function. Gene 154, 47-50.

Węgrzyn, G., Węgrzyn, A., Konieczny, l., Bielawski, K., Konopa, G., Obuchowski, M., Helinski, D. R. \& Taylor, K. (1995b). 
Involvement of the host initiator function $d n a A$ in the replication of coliphage $\lambda$. Genetics 139, 1469-1481.

Węgrzyn, G., Węgrzyn, A., Pankiewicz, A. \& Taylor, K. (1996). Allele specificity of the Escherichia coli dnaA gene function in the replication of plasmids derived from phage $\lambda$. Mol Gen Genet 252, 580-586.

Żylicz, M., Ang, D., Liberek, K. \& Georgopoulos, C. (1989).
Initiation of $\lambda$ DNA replication with purified host- and bacteriophage-encoded proteins : the role of the DnaK, DnaJ and GrpE heat shock proteins. EMBO J 8, 1601-1608.

Received 1 September 2000; revised 13 November 2000; accepted 27 November 2000. 